\title{
Cloning and analysis of the leuB gene of Leptospira interrogans serovar pomona
}

\author{
Min Ding and David B. Yelton* \\ Department of Microbiology and Immunology, Health Sciences Center, West Virginia University, PO Box 9177, \\ Morgantown, WV 26506-9177, USA
}

(Received 10 November 1992; revised 28 December 1992; accepted 6 January 1993)

\begin{abstract}
The leuB gene of Leptospira interrogans serovar pomona strain kenniwicki has been cloned on a $9.5 \mathrm{~kb}$ plasmid, pWVL1, by complementation of Escherichia coli leuB mutants. Subcloning and $T n 5$ mutagenesis showed that the region required for complementation was approximately $1.2 \mathrm{~kb}$ in length. Enzyme assays showed that the product of the cloned gene was a $\beta$-isopropylmalate dehydrogenase. Defects in the leuA, leuC and leuD genes of $E$. coli were not complemented by pWVL1. The nucleotide sequence of the leuB-complementing region and surrounding DNA has been determined. Three open reading frames were found which encode proteins of $40 \cdot 9,38.8$ and $15 \mathrm{kDa}$. Analysis of subclones containing nucleotide deletions of varying sizes showed that only the $38.8 \mathrm{kDa}$ protein was necessary to obtain complementation of $E$. coli leuB mutations. The PIR data base was searched and the enzyme 3-isopropylmalate dehydrogenase from six different micro-organisms was found to share significant amino acid sequence similarity $(43-57 \%$ ) with the $38.8 \mathrm{kDa} L$. interrogans leu $B$ gene product. The organization of the leucine biosynthetic genes in $L$. interrogans differs from that found in $E$. coli, Salmonella typhimurium and Bacillus subtilis.
\end{abstract}

\section{Introduction}

Leptospira is a genus composed of long, slender, helical, motile bacteria (Faine \& Stallman, 1982; Holt, 1978; Johnson, 1977, 1981). Phylogenetic analysis based on oligonucleotide cataloguing of bacterial 16S rRNAs suggests that the spirochaetes, including Leptospira, represent an early evolutionary divergence within the eubacteria (Fox et al., 1980; Paster et al., 1984). A distinguishing feature of leptospires is the use of longchain fatty acids or alcohols as their chief carbon and energy source (Holt, 1978; Johnson, 1977). Leptospires synthesize all of their amino acids except isoleucine by well-established biosynthetic pathways (Charon et al., 1974; Westfall et al., 1983).

Since Leptospira is a member of a group of bacteria which show an early evolutionary divergence from other eubacteria, the organization and control of genetic information in these bacteria may well differ from that in the better-studied eubacteria. Previous investigations

*Author for correspondence. Tel. (304) 293 4559; fax (304) 293 7823.

The nucleotide sequence data reported in this paper have been submitted to GenBank and have been assigned the accession number M59431. have demonstrated that, at least in some instances, the genetic organization seen in Leptospira does differ from that in other well-studied bacteria (Fukanaga \& Mifuchi, 1989; Richaud et al., 1990; Yelton \& Peng, 1989; Zuerner \& Charon, 1988). The goal of this study was to expand our understanding of leptospiral gene structure and organization.

Leucine biosynthetic genes were chosen as our investigative model because the leucine operon has been well studied in Escherichia coli, Salmonella typhimurium and Bacillus subtilis. The major biosynthetic pathway leading to leucine is the isopropylmalate pathway. In E. coli, $S$. typhimurium and $B$. subtilis there are three enzymes unique to leucine biosynthesis: 2-isopropylmalate synthase, the product of the leuA gene; isopropylmalate dehydratase, which consists of two subunits encoded by the leuC and leuD genes; and the NAD-dependent $\beta$ isopropylmalate dehydrogenase, the leuB gene product (Bartholomew \& Calvo, 1971; Parsons \& Burns, 1969; Umbarger, 1978; Ward \& Zahler, 1973). The four contiguous structural genes are transcribed as a unit and thus comprise an operon (Burns et al., 1966). Attenuation of transcription is the major, and probably only, control mechanism by which leucine regulates expression of the leucine operon (Gemmill et al., 1979, 1983; Searles et al., 1983; Ward \& Zahler, 1973). 
Little is known about the organization and control of the leucine biosynthetic genes in Leptospira (Richaud et al., 1990; Zuerner, 1986). The leuB genes have been cloned from $L$. interrogans serovar icterohaemorrhagiae (Richard et al., 1990) and L. biflexa serovar patoc (Zuerner, 1986), but these cloned genes have not been characterized or sequenced. The leuB gene cloned from L. interrogans serovar icterohaemorrhagiae was present on a $17.7 \mathrm{~kb}$ plasmid; subcloning localized the region necessary for $l e u B$ complementation to a $3.2 \mathrm{~kb} H$ indIII fragment obtained from the centre of the original plasmid (Richaud et al., 1990). Despite its size, the original plasmid was not able to complement mutations in other genes required for leucine biosynthesis (Richaud et al., 1990), suggesting that the genes necessary for such complementation were not located adjacent to the leuB gene. The leuB gene cloned from $L$. biflexa was localized to a $1.6 \mathrm{~kb}$ fragment of DNA by subcloning and transposon mutagenesis (Zuerner, 1986). This fragment of DNA was shown to encode a $43 \mathrm{kDa}$ protein by maxicell analysis (Zuerner, 1986). In this paper we report the cloning, characterization and nucleotide sequence of a gene from $L$. interrogans serovar pomona which complements a leuB defect in $E$. coli.

\section{Methods}

Materials. Restriction endonucleases and a nick-translation reagent kit were purchased from Bethesda Research Laboratories. $T_{4}$ DNA ligase was purchased from New England Biolabs. Calf alkaline phosphatase was purchased from Boehringer-Mannheim. ${ }^{35}$ S-dATP ( $\left.>1000 \mathrm{Ci} \mathrm{mmol}^{-1}, 10 \mathrm{mCi} \mathrm{m}^{-1}\right)$ and $\mathrm{L}-\left[{ }^{35} \mathrm{~S}\right]$ methionine $(>37 \mathrm{TBq}$ $\mathrm{mmol}^{-1}>1000 \mathrm{Ci} \mathrm{mmol}^{-1}, 10 \mathrm{mCi} \mathrm{m}^{-1}$ ) were purchased from Amersham. A ${ }^{77}$ Sequencing kit was obtained from Pharmacia. En ${ }^{3} \mathrm{Hance}$ was obtained from DuPont. All enzymes were used as recommended by the manufacturer.

Bacterial strains and phage. E. coli strain JA221 [ $\triangle$ trpE5 leuB6 hsdR $\left.\left(\mathrm{r}^{-} \mathrm{m}^{+}\right)\right]$was used as a recipient for the initial cloning experiments (Chinault \& Carbon, 1979; Yelton \& Charon, 1984) and was obtained from Dr John Carbon (University of California at Santa Barbara). Other E. coli strains used in this study were CV512 (leuA371); CV514 (leuB410); CV516 (leuB61), CV422 (leuC222); CV526 (leuD101); HB101 [hsdS $\left(\mathrm{r}^{-} \mathrm{m}^{-}\right)$, recA, proA, leuB6]; SE5000 (recA); and TB1 ( $h s d R, p r o A)$. The leucine auxotrophs were obtained from Dr Barbara Bachmann at the E. coli Genetic Stock Center; SE5000 was obtained from Dr Lola Stamm (University of North Carolina), and TB 1 from Dr Thomas Baldwin (Texas A \& M University). Strains of $L$. interrogans serovar pomona type kennewicki and $L$. biflexa serovar patoc were used as sources of DNA and were obtained from Dr Richard Zuerner (National Animal Disease Center, Ames, Iowa) and Dr Nyles Charon (West Virginia University), respectively. The $\lambda:: \operatorname{Tn} 5$ hybrid, $\lambda 467$ (b221 rex::Tn5, cI857, Oam29, Pam80), was utilized for transposon mutagenesis studies and was obtained from Dr Nancy Kleckner (Harvard University).

Media. E. coli strains were routinely propagated in LB broth at $37^{\circ} \mathrm{C}$, except when acting as hosts for screening the leuB gene, or for Tn 5 mutagenesis studies, in which case they were incubated at $30^{\circ} \mathrm{C}$. M9 medium was prepared according to Maniatis et al. (1982) and used to characterize transformants. YM broth was used to grow E. coli recipients for $\lambda 467$ infections (de Bruijn \& Lupski, 1984). Leptospira strains were propagated on the modified Tween- 80 albumin salt medium (EMJH) of Johnson (Johnson \& Harris, 1967).

DNA extraction and cloning. Leptospira DNA was extracted and purified as previously described (Yelton \& Charon, 1984). Plasmid DNA was purified from $E$. coli cells grown overnight in $250 \mathrm{ml}$ cultures (Davis et al., 1980). DNA from $L$. interrogans serovar pomona was partially digested with $E c o$ RI and ligated to EcoRI-digested, calfalkaline-phosphatase-treated pUC13 (Vieira \& Messing, 1982). Ligated DNA was used to transform E. coli JA221 using the procedure of Kushner (1978). Ampicillin-resistant (Amp ${ }^{r}$ ) transformants were selected at $30^{\circ} \mathrm{C}$.

Gel electrophoresis and DNA-DNA hybridization. Electrophoresis was performed as described by Maniatis et al. (1982). Specific DNA fragments were purified by electroelution from agarose followed by passage through Elutip-d columns (Schleicher and Schuell). Purified DNA fragments were radiolabelled by nick-translation using ${ }^{35} \mathrm{~S}$ dATP. DNA-DNA hybridizations were done as described by Maniatis et al. (1982). The conditions used for DNA-DNA hybridization allowed approximately $6 \%$ (high stringency) or $40 \%$ (low stringency) base mismatch.

Transposon mutagenesis. Mutagenesis was performed with Tn5 contained in $\lambda 467$ using the procedure described by de Bruijn \& Lupski (1984). E. coli HB101 harbouring pWVL5 was transduced to kanamycin resistance $\left(\operatorname{Kan}^{r}\right)$ with $\lambda 467$. The plasmid DNA was extracted from $\mathrm{Kan}^{\mathrm{r}}$ transformants and then transformed into $E$. coli JA221. The phenotypes of the Tn5-modified plasmids in $E$. coli JA221 were determined by replica plating to selective media. The Tn5 insertion sites were located by restriction enzyme mapping of the mutated plasmid DNAs (de Bruijn \& Lupski, 1984; Lawn et al., 1978).

Maxicell analysis. E. coli SE5000 containing various plasmids was used for maxicell analysis as described by Sancar et al. (1979). Cells were labelled with $\left[{ }^{35} \mathrm{~S}\right]$ methionine for $1 \mathrm{~h}$ at $30^{\circ} \mathrm{C}$, then harvested and lysed by boiling in electrophoresis sample buffer. For analysis, equal amounts of the resulting lysates were electrophoresed at $150 \mathrm{~V}$. After electrophoresis, the gels were analysed by fluorography using En ${ }^{3}$ Hance.

Measurement of enzyme activity. 2-Hydroxy-4-methyl-3-carboxyvalerate: $\mathrm{NAD}^{+}$oxidoreductase (EC 1.1.1.85; $\beta$-isopropylmalate dehydrogenase) activity was measured at $37^{\circ} \mathrm{C}$ in crude extracts by the procedure of Parsons \& Burns (1969). Protein determinations were performed using a kit from BioRad employing the Bradford assay (Bradford, 1976). The substrate, $\beta$-isopropylmalate, was obtained from Dr John Schloss (E. I. Dupont Co., Wilmington, DE).

DNA sequencing and analysis. DNA sequencing was performed by the dideoxy chain-termination method of Sanger et al. (1977). Sequential, overlapping deletions of the cloned DNA molecule were constructed by exonuclease III and S1 nuclease treatment (Erase-a-base kit; Promega) as described by Henikoff (1984). Double-stranded DNA templates were prepared by the alkaline lysis procedure of IshHorowicz \& Burke (1981). ${ }^{35}$ S-dATP and T7 DNA polymerase (Pharmacia) were used for the sequencing reactions. Analysis of the sequence data was done using the DNASTAR program.

\section{Results}

Cloning the leuB gene of L. interrogans

A genomic library containing approximately $4000 \mathrm{Amp}^{\mathrm{r}}$ transformants on LB agar plates was constructed for $L$. 


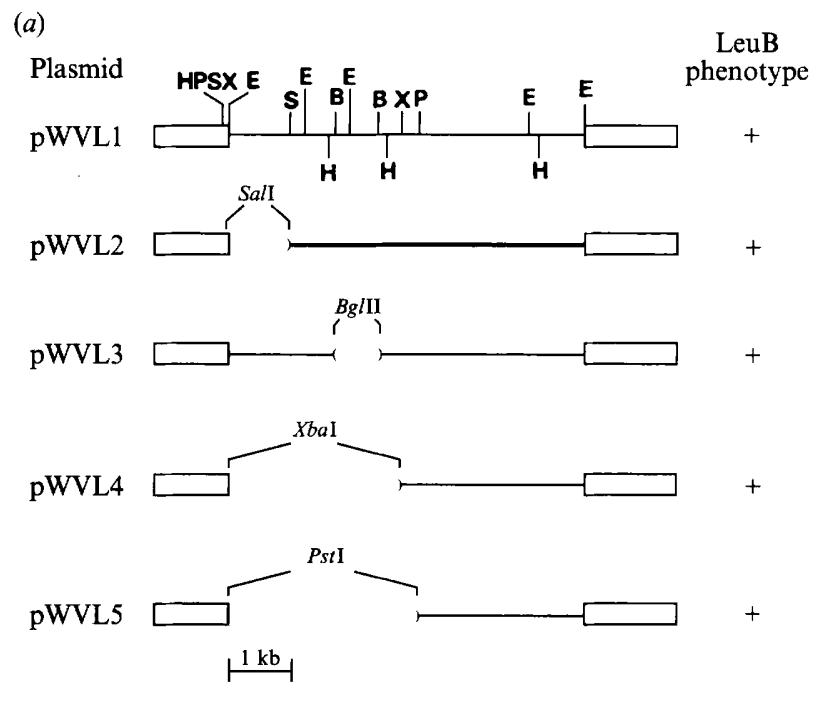

(b)

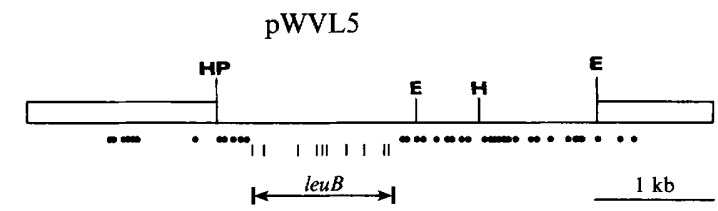

Fig. 1. Subclone and transposon mutagenic analysis of pWVL1. (a) Subclones were produced from pWVLl by digesting the plasmid to completion with a restriction endonuclease and then self-ligating the fragment containing the vector. The phenotypes of the various subclones were determined. The single lines represent Leptospira DNA; the boxes represent $\mathrm{pUC13}$ DNA. The deleted regions are indicated by parentheses. Abbreviations for restriction enzymes are as follows: B, BglII; E, EcoRI; H, HindIII; P, PstI; S, SalI; X, Xbal. (b) Tn5 insertions into pWVL5 were obtained as described in the text. The phenotype of the cells harbouring the plasmid containing $\operatorname{Tn} 5$ was determined by plating on the appropriate media; the location of the Tn 5 insertion was determined by restriction enzyme digestion. The dots indicate insertions having a $\mathrm{LeuB}^{+}$phenotype; the vertical lines indicate insertions having a $\mathrm{LeuB}^{-}$phenotype.

interrogans in E. coli JA221 (leuB6) using pUC13 as the vector. Analysis of $\beta$-galactosidase activity indicated that approximately $96 \%$ (481 of 500) of the Amp ${ }^{r}$ transformants contained insertions into the EcoRI site of pUC13. Colonies representing the entire library were mixed together, grown in LB broth for $2 \mathrm{~h}$ at $37^{\circ} \mathrm{C}$, pelleted by centrifugation, washed twice with $\mathrm{M} 9$ medium and plated onto M9 salts agar containing tryptophan and ampicillin. These plates were incubated at $30^{\circ} \mathrm{C}$ for $6 \mathrm{~d}$. Approximately 300 leucine-independent $\left(\mathrm{Leu}^{+}\right)$colonies were obtained. Plasmid DNA was isolated from three of these colonies. Each of the three colonies contained a $9.5 \mathrm{~kb}$ plasmid; these plasmids were shown to be identical by digestion with EcoRI. One of these plasmids was designated pWVL1 and used for further analysis. A restriction map of pWVL1 (Fig. 1a) was generated as described (de Bruijn \& Lupski, 1984;
Lawn et al., 1978). To ensure that the $\mathrm{Leu}^{+}$transformants were not revertants, pWVL1 was used to retransform $E$. coli strain JA221 to Amp ${ }^{\mathrm{r}}$. These colonies were then screened for leucine independence. As a control, strain JA221 transformed with pUC13 was used. All of the cells transformed with pWVL1 DNA simultaneously became $\mathrm{Amp}^{\mathrm{r}}$ and $\mathrm{Leu}^{+}$. None of the cells transformed to $\mathrm{Amp}^{\mathrm{r}}$ with pUC13 became $\mathrm{Leu}^{+}$.

\section{Allele-specific complementation test}

Hottinger et al. (1987) reported that a cloned serine tRNA gene from Lactobacillus bulgaricus was able to specifically complement the E. coli leuB6 mutation, but was not able to complement the $E$. coli leuB401 and leuB61 mutations. They suggested that this allele-specific complementation of $E$. coli leuB6 occurs by missense suppression. pWVL1 was introduced into different strains of E. coli [JA221 (leuB6), CV514 (leuB401) and CV516 (leuB61)] which carried independent mutations in their leuB genes. The leptospiral gene present on pWVL1 was able to complement all three leuB mutations, suggesting that we had cloned the leuB gene and not the gene for some suppressor tRNA molecule.

Screening for complementation of leucine auxotrophs by $p W V L 1$

The genes for the leucine biosynthetic enzymes are organized in operons in E. coli, S. typhimurium and $B$. subtilis (Somers et al., 1973; Ward \& Zahler, 1973). Assuming that the corresponding genes are organized analogously in $L$. interrogans, the size of the cloned DNA fragment in pWVL1 suggested the possibility that other leucine biosynthetic genes might be found on the fragment. To test this, E. coli strains CV512 (leuA), CV422 (leuC) and CV526 (leuD) were transformed with pWVL1. The Amp ${ }^{r}$ colonies obtained following transformation were replica plated onto minimal medium which lacked leucine. No complementation of the leuA, leuC or leuD mutations was obtained with pWVL1.

\section{Localization of the leuB gene}

In $E$. coli the $l e u B$ gene occupies approximately $1 \mathrm{~kb}$ of DNA (Friedberg et al., 1985). Because of the large size of pWVL1, subcloning onto smaller fragments was used to help localize the $L$. interrogans leuB gene. pWVL1 was digested to completion with SalI, BglII, XbaI or PstI. Those DNA fragments which still contained pUC13 vector were self-ligated to create subclones pWVL2, pWVL3, pWVL4 and pWVL5 (Fig. 1a). After transformation into $E$. coli JA221, Amp ${ }^{\mathrm{r}}$ clones were selected 


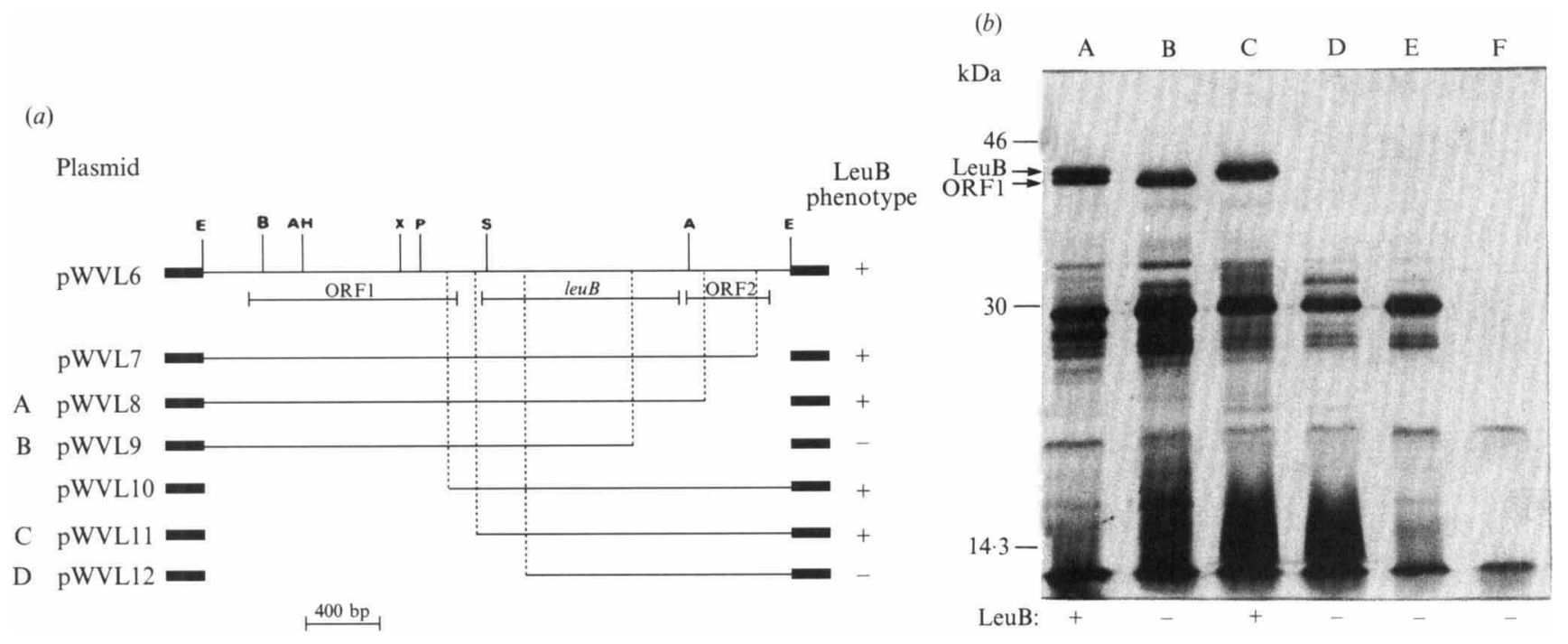

Fig. 2. Deletion and maxicell analysis of pWVL6. (a) Deletions were introduced into pWVL6 using exonuclease III. The resulting plasmids were introduced into $E$. coli JA221 and their ability to complement the leuB mutation in these cells was determined. The boxes represent pUC13 DNA and the single lines represent Leptospira DNA. The extent of the deletion is indicated by the dotted vertical line. Abbreviations for restriction enzymes are as follows: A, AvaI; B, BglII; E, EcoRI; H, HindIII; P, PstI; S, SalI ; X, XbaI. The letters to the left of the plasmids refer to the lanes in part $(b)$ of the figure. $(b)$ The number of proteins produced by the various deletioncontaining plasmids was determined using maxicells. The upper arrow indicates the $42 \mathrm{kDa}$ protein (lanes $\mathrm{A}$ and $\mathrm{C}$ ) required for complementation of the leuB mutation in E. coli. The lower arrow indicates the $40 \mathrm{kDa}$ protein (lanes A and B) encoded by ORF1. Lanes: A, pWVL8; B, pWVL9; C, pWVL11; D, pWVL12; E, pGEM-4; F, no plasmid.

Table 1. Enzyme assays

\begin{tabular}{lc}
\hline \hline Bacterial strain/plasmid & $\begin{array}{c}\text { Specific activity* of } \\
\beta \text {-isopropylmalate } \\
\text { dehydrogenase }\end{array}$ \\
\hline E. coli TB1 (leucine prototroph) & $0 \cdot 20 \pm 0 \cdot 04$ \\
E. coli CV516 (leuB61)/pWVL11 & $0 \cdot 19 \pm 0 \cdot 07$ \\
E. coli CV516 (leuB61) & $0 \cdot 00$ \\
L. interrogans (leucine prototroph) & $0.055 \pm 0.01$ \\
\hline \hline
\end{tabular}

* The specific activity of the enzyme was determined from the linear portion of the reaction curve and is expressed as $\mu \mathrm{mol} \alpha$-ketoisocaproic acid produced $\min ^{-1}(\mu \mathrm{g} \text { protein })^{-1}$. The data represent the means \pm the standard deviations of the means obtained from a minimum of three experiments performed in duplicate.

and tested for their abilities to complement the leuB6 defect in $E$. coli JA221. Cells containing any one of the four plasmids obtained by subcloning were $\mathrm{Leu}^{+}$. This result indicated that the leuB-complementing activity was located within the $3.5 \mathrm{~kb}$ leptospiral DNA fragment found in pWVL5.

As the fragment of $L$. interrogans serovar pomona DNA contained in pWVL5 was still considerably larger than the corresponding coding region for $l e u B$ in $E$. coli (Friedberg et al., 1985), transposon mutagenesis with Tn 5 was performed on pWVL5 to further localize the functional region of the leuB gene. A total of 48 independent $\mathrm{Kan}^{\mathrm{r}}$ and $\mathrm{Amp}^{\mathrm{r}}$ colonies were examined for their leucine phenotypes; 38 of the colonies were $\mathrm{Leu}^{+}$ and 10 were $\mathrm{Leu}^{-}$. The locations of the $\mathrm{Tn} 5$ insertions were determined by digestion with restriction enzymes and subsequent sizing of the fragments (de Bruijn \& Lupski, 1984). The results are shown in Fig. 1(b). The region of the leptospiral DNA required for $l e u B$ function was approximately $1.2 \mathrm{~kb}$ in length.

\section{Southern blot analysis}

To ensure that the DNA which had been cloned originated from $L$. interrogans serovar pomona, Southern blot analysis was performed. pWVL1 DNA was purified by two successive bandings in $\mathrm{CsCl}$ /ethidium bromide gradients and was then digested with Pst $\mathrm{I}$ and EcoRI. The resulting $2 \mathrm{~kb}$ fragment which contained the leuB complementing activity was isolated and labelled with ${ }^{35}$ S-dATP by nick-translation. The labelled DNA was used to probe Southern blots which contained EcoRIdigested pUC13 DNA and EcoRI-digested DNA isolated from E. coli, L. biflexa serovar patoc and $L$. interrogans serovar pomona. Under conditions of high stringency, a single hybridizing band of $3.1 \mathrm{~kb}$ was detected using the probe and serovar pomona DNA; no hybridization with pUC13, E. coli, or L. biflexa DNAs was detected (data not shown). 


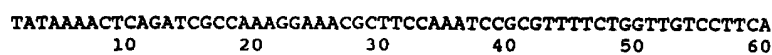
$\begin{array}{ccccc}\text { TCGGACGTGATTCAAGTCATTTTAGAAGGAAATGCAAAACTCACAATCCGACCTTCCGGA } \\ 70 & 80 & 90 & 100 & 110\end{array}$ $\begin{array}{ccc}\text { ACGAACCTAAAATTAAAATTTATTCTTCCTTTCAAAGCCTAAAAGCTCCTAAGTCCAAAG } \\ 130 & 140 & 150\end{array}$

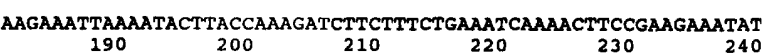
MetAsnAspalaAspIleHisLysGluLeuPheGlnHi

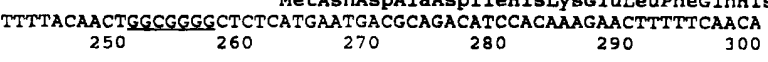

ThrLysG IuLeuAlaAspHisTyrLeuLeuAsnThrTyrAlaArgTyrAspValAlaPhe

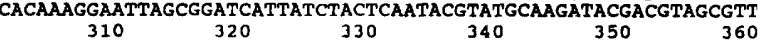

ArgTYrGlyValAsngluLeuLeuPheAspPheAspAsnLysGInTyrI leAspPheH is

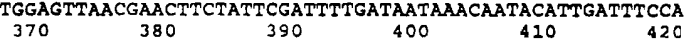

CysGlyValAlaValThrAsnLeuglyHisAlaAspProAspIleIleGluvalValArg

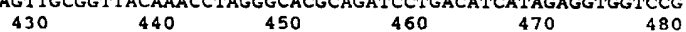

SerGInAlaAspLysLeuPheHisThrSerAsnLeuPheTyrSerGlugluAlaSerLys

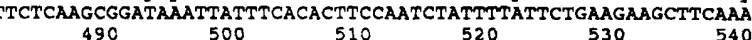

LeuAlaGluLeuI leI leLeuAsnSerPheProGly LysValPheLeuThrAsnSerGly ACTTGCAGAACTTATCATATTAAATTCCTTTCCTGGAAAAGTGTTTTTAACCAATTCAGG $\begin{array}{lllll}550 & 560 & 570 & 580 & 590\end{array}$

ThrGluAlaIlegluglyAlaPheLysLeuAlaArgLysTyrAlaTyrSerLysArgIle AACCGAAGCGATCGAAGGAGCATTTAAACTCGCAAGAAAATACGCATATTCAAAAAGAAT

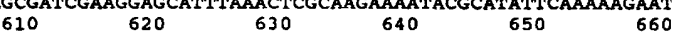

ValAspProIleIleLeuSerLeuGluLysSerPheH isGlyArgSerValserGlyMet CGTAGATCCTATCATCCTTTCCTTGGAAAAAAGTTTTCACGGAAGATCCGTTTCGGGTAT $670 \begin{array}{lllll}680 & 690 & 700 & 710 & 720\end{array}$

SerLeuThrGlYG InAspLysI leArgLYSGIYTYrGlyGluLeuLeuLYsGlyI leGlu

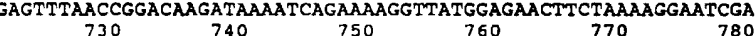

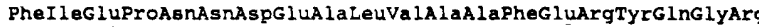
ATTTATAGAACCGAACAACGACGAAGCCCTTGTAGCGGCATTCGAAAAGTACCAGGGAAG

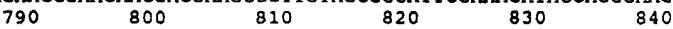

IleValAlaLeuI leGluGluProI leLeuG YyGluSerGlyI leI leProLeuSerArg AATCGTAGCCTTAATCGAAGAACCCATCTTAGGCGAAAGTGGAATTATACCTTTATCTAG C50

AsnPheLeuThrLeuSerArgGluLeuThrGIUGluAsnG luAla LeuLeuI lePheAsp AAATTTCCTTACACTTTCCAGAGAACTAACAGAAGAAAACGAAGCGCTTCTAATTTTCGA $\begin{array}{llllll}910 & 920 & 930 & 940 & 950 & 960\end{array}$ GluIleGInThrGlyMetGlyArgThrGlyThrLeuPheAlaPheGluThrMetGlyPhe $\begin{array}{ccccc}\text { CGAAATCCAAACCGGATGGGTAGAACTGGAACGTTATTCGCATTTGAAACGATGGGTTT } \\ 970 & 980 & 990 & 1000 & 1010\end{array}$

SerProAspalaMetThrLeUA laLysGlyLeuGlySerGlyPheProI leglyAlaLeu SAGTCCAGA CGCAATGACACTTGCCAAAGGGCTCGGATCTGGATTTCCGATCGGCGCTTT

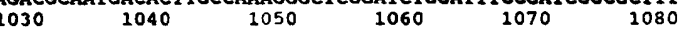

IleValGlyGluLysTyrGlnAspLauPheThrGlnGlySerHisGlySerThrPheGly

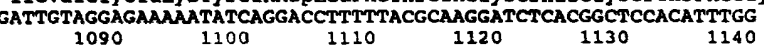

GlYAsnH isLeuAlaAlaAlaValAlaTyrG LuThrI leArgI leI leGlnThrArgGlu AGGTAATCATTTGGCTGCTGCAGTCGCTTATGAAACGATTCGTATCATTCAAACCAGAGA

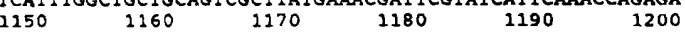

IleLeuAsnAsnvalAsnI leCysSerAspI leAlaPheThrArgLeuArgGluMetGln

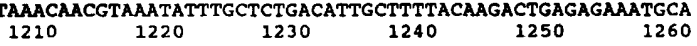

GIULYSTyrProVa I I eSerGI UVa IArgGIYLYsGlyLeuHisIleGlyLeuGluLeu $\begin{array}{cccccc}\text { GGAAAAATATCCAGTGATTTCAGAAGTAGAGGAAAGGACTTCACATCGGACTTGAATT } \\ 1270 & 1280 & 1290 & 1300 & 1310 & 1320\end{array}$ $\begin{array}{lllll}1270 & 1280 & 1290 & 1300 & 1310\end{array}$

LysValproSerArgProIleAlagluAlacysLeuSerGlnglySer ** *

GAAAGTTCCTTCCAGACCAATTGCGGAAGCCTGTTTGTCGCAGGGCTCGTAGTCAATGCA $1370 \quad 1380$

ACGGCGGATAACGTAGTTCGGATTATGCCCCACTTACAATTTCGACAGATTTTTTAAAT

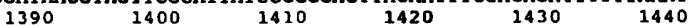

CAaggattagacatctragaAtccgtactcaAacaAaActaaAaggatctaAaAaAgat Met $\begin{array}{lllll}1450 & 1460 & 1470 & 1480 & 1490\end{array}$

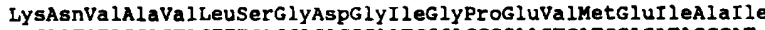
GAAGAATGTAGCAGTACTTTCAGGAGACGGAATCGGACCGGAAGTCATGGAGATAGCCAT $\begin{array}{llllll}1510 & 1520 & 1530 & 1540 & 1550 & 1560\end{array}$

SerValLeutysLysAlaLeuGlyAlaLysVa1 SerGluPheGlnPheLysGluglyPhe $\begin{array}{ccccc}\text { CTCCGTTTGAAAAAGCTCTCGGTGAAAAGTTTCCGAGTTTCAATTTAAAGAAGGATT } \\ 1570 & 1580 & 1590 & 1600 & -1610\end{array}$

ValGlyGlyIleAlaIleAsplysThrGlyHisProLeuProProGluThrLeuLysLeu TGTAGGTGGAATCGCAATCGATAAAACTGGACACCCACTTCCACCGGAAACTCTTAAACT
CYsGluGluSerSerAlaI leLeuPheGlySerVaIGlyGlyProLysTrpGluThrLeu ATGTGAAGAATCTTCCGCAATTCTTTTCGGAAGTGTGGGAGGTCCTAAATGGGAAACACT ProProGluLYsGInPrOGIUArgGIYAlaLeuLeuProLeUArgLYsHisPheAspLeu $\begin{array}{cccc}\text { CCCTCCGGAAAAACAACCGGAACGAGGGCACTTCTACCTTTGAGAAAACATTTTGATCT } \\ 1750 & 1760 & 1770 & 1780\end{array}$ PheAlaAsnLeuArgProAlaIleIleTyrProGluLeuLysAsnAlaserProValarg ATTTGCAAACTTAAGACCTGCGATCATTTATCCAGAGTTGAAAAATGCTTCTCCAGTTCG

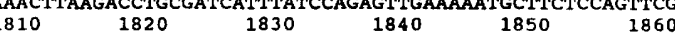

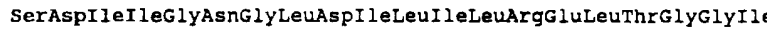
$\begin{array}{ccccc}\text { TTCTGATATTATTGGAACGGATTAGATATTCTCATATTAAGAGAGTTAACCGGAGGAAT } \\ 1870 & 1880 & 1890 & 1900 & 1910\end{array}$

TyrPheGlyGlnProLysGlyArgGluGlySerGlyGInGluGluPheAlaTyrAspThr TTATTTTGGACAACCAAAAGGAAGAGAAGGATCAGGTCAGGAAGAATTTGCATACGACAC $930 \quad 1940 \quad 1950 \quad 1960 \quad 1970 \quad 1980$

MetLysTyrSerArgArgGluI leGluArgI leAlaLysValAlaPheGInAlaAlaArg 1990

sArgAsnAsnLysValThrSerI leAspLysAlaAsnValLeuThrThrSerValPhe AAAGAAATAATAAAGTGACTAGTATCGATAAAGCAAACGTCTTGACTACTTCCGTTTT $205022060 \quad 2070 \quad 2080 \quad 2090 \quad 2100$

TrpLysG luValValI leG luLeuH isLysLysG luPheSerAspVa IGInLeuAsnHi

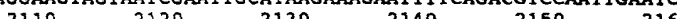

LeuTyrVa lAspAsnAl aAlaMetGInLeuI leValAsnProLysGlnPheAspValVa TCTTTATGTGGACAATGCGGCGATGCAGTTAATCGTAAATCCGAAACAATTCGACGTGGT LeuCYsG IuAsnMetPheGlYAspI leLeuSerAspGluAlaSerIleIleThrGlyse: TCTTTGTGAGAATATGTTTGGTGATATTCTTTCGGACGAGGCTTCCATCATTACGGGTTC $\begin{array}{llllll}2230 & 2240 & 2250 & 2260 & 2270 & 2280\end{array}$

IleGlyMetLeuProSerAlaSerLeuSerGluSerGl yPheGl yLeuTYrGluProSe AATCGGAATGCTTCCTTCTGCCTCTCTTTCCGAATCTGGATTTGGATTGTATGAACCTTC $\begin{array}{llllll}2290 & 2300 & 2310 & 2320 & 2330 & 2340\end{array}$

GlYGlySerAlaProAspI leAlaglyLYSGIYValAlaAsnProIleAlaglnValLel TGGTGGTTCTGCGCCGGACATAGCCGGAAAAGGAGTGGCAAATCCGATTGCTCAAGTATT

SerAlaAlaLeuMet LeUArgTyrSerPheSerMetgluglugluAlaAsnLys Ileglu GAGTGCGGCGTTGATGTTACGTTATTCTTTTTCTATGGAAGAAGAAGCAAACAAGATAGA $\begin{array}{llllll}2410 & 2420 & 2430 & 2440 & 2450 & 2460\end{array}$

ThrAlaValArgLYSThrI IeAlaSerGlyLysArgThrargAspI leAlagluvalGly AACCGCCGTGCGTAAAACGATTGCCTCCGGAAAAAGAACCAGAGACATAGCGGAAGTAGG $\begin{array}{lllll}2470 & 2480 & 2490 & 2500 & 2510\end{array}$

SerThrI leValglyThrLysGluI leGlyGlnLeuI leGluSerPheLeu * * CATCGTAGGAACTAAAGAAATCGGTCAATTGATCGAATCCTTTCTCTAAAAAGA MetLYsAlaglyValAlaProAsnglyArgProTyrglnValLeur leAl

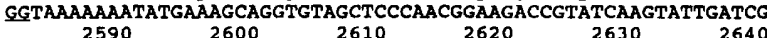

GluAsnSerArgPheGInAlaLysG InLeUALaGInIleLeuGluSerGluGlyTyrGl

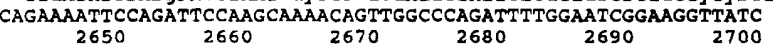

ValI leGlyPheAlaGluAsnGlyLysGluLeuValLysLeuTyrAspgluH isArgLe AAGTGATTGGGTTTGCAGAGAACGGAAAGGACTCGTCAAACTCTATGATGAACACAGAC

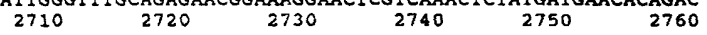

ValAspLeuI leThrLeuAspLeuAsnLeuProValMetAspG IyTyrAlaThrPhePhe

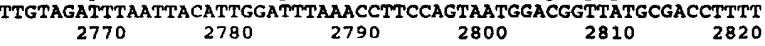

GluI leLYsGlyLysGlyValLeuProArgI leValI leValserGlugluAsnThrPro TTGAAATTAAAGGAAAAGGAGTTCTTCCCAGAATTGTAATCGTTTCCGAAGAGAATACC

Alaval LeuLysAsnLeuI leAspgluglyalaMetAspTyrI leProLysProI leLys CCGCCGTTTTAAAAAATCTTATAGACGAAGGTGCAATGGATTATATTCCAAAACCGATTA

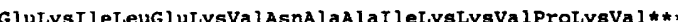

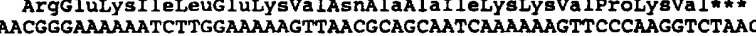

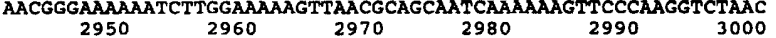
CTTCTTTCCAAATCAAATTCAGATTTCTTCCTACTTCTTTTTTACGATGACTGAAGAAAT

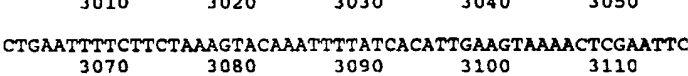

Fig. 3. Nucleotide sequence. The nucleotide sequence of the cloned $3.1 \mathrm{~kb} E c o$ RI fragment obtained from pWVLl is shown, with the deduced amino acid sequences of the three ORFs. Potential Shine-Dalgarno sequences are underlined. 


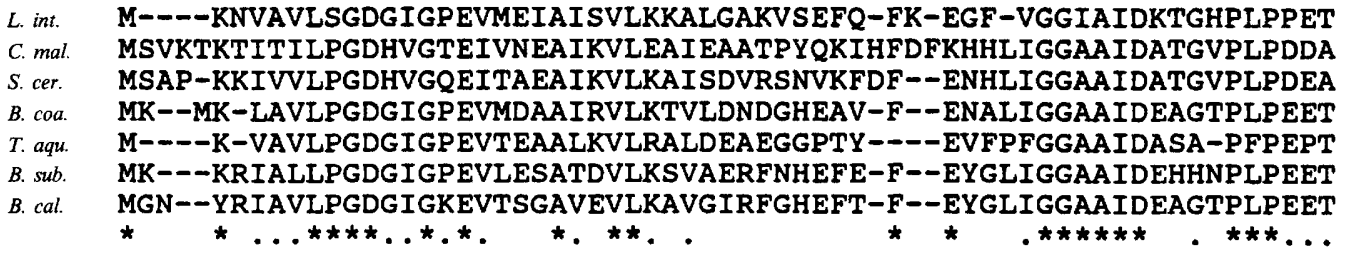

L. int.

C. mal.

S. cer.

B. coa.

T. aqu.

B. $s u b$.

B. cal.

L. int.

C. mal.

S. cer.

B. coa

T. aqu.

B. sub.

B. cal.

L. int

C. mal

S. cer.

B. coa.

T. aqu.

B. sub.

B. cal.

L. int.

C. mal.

S. cer.

B. coa.

T. aqu.

B. sub.

B. cal.

L. int.

C. mal.

S. cer.

B. coa.

T. aqu.

B. sub.

B. cal.

LKLCEESSAILFGSVGGPKWETLPPEKQPERGALLPLRKHFDLFANLRPAI-IYPELKNASPVRS LESAKNSDAVLIGAVGGPKWGT--GALRPEQG-LLKIRKELNLYANIRPCNFASDSLLELSPLRP LEASKKVDAVLLGAVGGPKWGT--GSVRPEQG-LLKIRKELQLYANLRPCNFASDSLLDLSPIKP LDICRRSDAILLGAVGGPKWDHNPASLRPEKG-LLGLRKEMGLFANLRPVK-AYATLLNASPLKR RKGVEEAEAVLLGSVGGPRLGRPSPQDPPGDG-ASFLKEKPDLFANLRPAK-VFPGLERLSPLKE VAACKNADAILLGAVGGPKWDQNLSELRPEKG-LLSIRKQLDLFANLRPVK-VFESLSDRSPLKK VRLCRESDAVLLGAVGGPKWDDNPPHLRPEKG-LLAIRKQLDLYANLRPVV-CYDSLVSRSPLKP

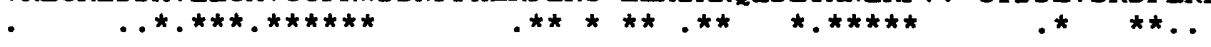

DIIGNGLDILILRELTGGIYFGQPKGREGS--GQEEFAYDTMKYSRREIERIAKV-AF-QAARKR EVV-KGTNLI IVRELVGGIYFGDREEQEESADKQT--AWDTEKYTVDEVTRITRMAAFMALQHTP QFA-KGTDFVVVRELVGGIYFGKRKEDD----GDGV-AWDSEQYTVPEVQRITRMAAFMALQHEP ERV-ENVDLVIVRELTGGLYFGRPSERRGP--GENEV-VDTLAYTREEIERIIEK-AF-QLAQIR EIA-RGVDVLIVRELTGGIYFGEPRGM-----SEAE-AWNTERYSKPEVERVARV-AF-EAARKR EYI-DNVDFVIVRELTGGLYFGQPSKRYVNTEGEQE-AVDTLFYKRTEIERVIRE-GF-KMAATR DLV-QGVDFVIVRELTGGIYFGQPSA--VVENGE-EKAVDTLLYKKEEIERIVRM-AF-ELARGR

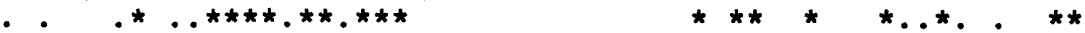

NNKVTSIDKANVLTTSVFWKEVVIELHKKEFSDVQLNHLYVDNAAMQLIVNPKQFD-VVLCENMF PLPIWSLDKANVLASSRLWRRTVDKVISEEFPTLSVQHQLIDSAAMILIQNPTKLNGI I ITSNMF PLPIWSLDKANVLASSRLWRKTVEETIKNEFPTLKVQHQLIDSAAMILVKNPTHLNGI I ITSNMF RKKLASVDKANVLESSRMWREIAEETAKK-YPDVELSHMLVDSTSMQLIANPGQFD-VIVTENMF RKHVVSVDKANVLEVGEFRRKTVEE-VGRGYPDVALEHOYVDAMAMHLVRSPARFD-VVVTGNIF KGKVTSVDKANVLESSRLWREVAED-VAQEFPDVKLEHMLVDNAAMQLIYAPNQFD-VVVTENMF RKKVTSVDKANVLSSSRLWREVAEE-VANEFPDVTLEHMLVD-MRMQLIRAPKQFD-VIVTENMF

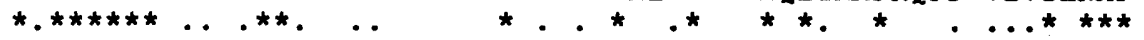

GDILSDEASIITGSIGMLPSASL-S----ESGFGLYEPSGGSAPDIAGKGVANPIAQVLSAALML GDIISDEASVIPGSLGLLPSASLASLPDTNTAFGLYEPCHGSAPDLPANKV-NPIATILSAASML GDIISDEASVIPGSLGLLPSASLASLPDKNTAFGLYEPCHGSAPDLPKNKV-DPIATILSAAMML GDILSDEASVITGSLGMLPSASLRS-----DRFGMY EPVHGSAPDIAGQGKANPLGTVLSAALML GDILGNLRADLPGSLGLLPSASL------GRGTPVFEPVHGSAPDYAGKGR-NPTAAILSAAMMI GDILSDEASMLTGSLGMLPSASL-S----SSGLHLFEPVHGSAPDIAGKGMANPFAAILSAAMLL GDILSDEASMLSGSLGMLPSASL-S----ASGPSLYEPVHGSAPDIAGMNKANPIAAILSAAMMI

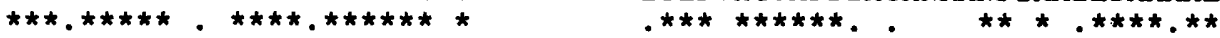

RYSFSMEEEANKIETAVRKTIASGKRTRDIAEVG----STIVGTKEIGQLIESFL--------RLSLDCVKEAEALEEAVKQVLDKGIRTADLRGTS----STTEVGDAIVEAVTKILKEKA----KLSLNLPEEGKAIEDAVKKVLDAGIRTGDLGGSN----STTEVGDAVAEEVKKILA------RYSFGLEKEAAAIEKAVDDVLQDGYCTGDLQVANGKVVSTIELTDR---IIEKLNNSAARPRIFO E-QLRPGGLARKVEDAAKALLET--PPPDLGGSE-----ARAFTATV--LRH--LA-------RTSFGLEEEAKAVEDAVNKVLASGKRTRDLARSEEFS-STQAITEEVKAAIMSENTISNV----RLSFGLTAEAGGRAR-VWQALALG-SGSRLGQRRPHL-STNEMVEEIKAAVLDYTAIAQIMTVYA-

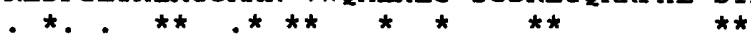

Fig. 4. Alignment of the amino acid sequences of various $\beta$-isopropylmalate dehydrogenases. The sequences have been aligned using the MACAW program (Schuler et al., 1991). Where necessary, to enhance the alignments, gaps have been introduced and are indicated by dashes. An amino acid residue appearing in at least six of the seven sequences is indicated by an asterisk; a residue appearing in at least five of the seven sequences or a residue where a related amino acid has been substituted is indicated by a dot. Abbreviations: L. int., Leptospira interrogans; C. mal., Candida maltosa; S. cer., Saccharomyces cerevisiae, B. coa., Bacillus coagulans; T. aqu., Thermus aquaticus; B. sub., Bacillus subtilis; B. cal., Bacillus caldotenax.

\section{Maxicell analysis}

The protein product of cloned $l e u B$ gene was identified by using maxicells (Sancar et al., 1979). For these studies, plasmid pWVL6 was produced by subcloning the internal $3 \cdot 1 \mathrm{~kb}$ EcoRI fragment of pWVL1 (Fig. $1 a$ ) into pGEM4 (Promega). Subclones of pWVL6, containing nucleotide deletions of varying sizes, were constructed and tested for their leuB-complementing activity. E. coli SE5000 was transformed with various plasmid subclones (Fig. $2 a$ ) and the resulting transformants were analysed to determine the number and the sizes of the proteins necessary for $l e u B$ function (Fig. $2 b$ ). A $42 \mathrm{kDa}$ protein and a $40 \mathrm{kDa}$ protein were produced by the cloned DNA. A third open reading frame (ORF), potentially encoding a $15 \mathrm{kDa}$ protein, has been identified within the 


\author{
H. sap. MFSKLAHLQRFAVLSRGVHSSVASATSVATKKTVQGPPTSDDIFEREYKYGAHNYHPLPVALERG \\ $S$ cer. \\ L. int.
}

s. cer. KGAHLWDPEGKLYLDFLSAYSAVNQGHCHPHI IKALTEQAQTLTLSSRAFHNDVYAQFAKFVTEF

L. int. VNELLFDFDNKQYIDFHCGVAVTNLGHADPDI I EVVRSQADKLFHTSNLFYSEEASKLAELII I

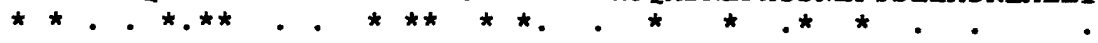

H. sap. FNYH-KVLPMNTGVEAGETACKLARKWGYTVKGIQKYKAKIVFAAGNFWGRTLSAISSSTD-PTSY S. cer. SGFE-TVLPMNTGAEAVETALKLARRWGYMKKNI PQDKAIILGAEGNFHGRTFGAISLSTDYEDSK L. int. NSFPGKVFLTNSGTEAIEGAFKLARKYAYSKRIVDP---IILSLEKSFHGRSVSGMSLTGQDKIRK

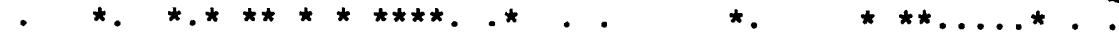

H. sap. DGFGPFMP-----GFDI I PYNDLPALERALQDP---NVAAFMVEPIQGEAGVVVPDPGYLMGVRS. cer. LHFGPFVPNVASGHSVHKIRYGHAEDFVPILESPEGKNVAAIILEPIOREAGIVVPPADYFPKVSL. int. -GYGELL-----KGIEFIEPNNDEALVAAFERYQGR-IVALIEEPILGESGII-PLSRNFLTLSR .*.. $\quad . . *$. . . . . . *

H. sap. ELCTRHQVLFIADEIQTGLARTGRWLAVD-Y-ENVRPDIVLLGKALSGGLYPVSAVLCDDDIMLT S. cer. ALCRKHNVLLIVDEIQTGIGRTGELLCYDHYKAEAKPDIVLLGKALSGGVIPVSCVLSSHDIMSC L. int. ELTEENEALLIFDEIQTGMGRTGTLFAFE-T-MGFSPDAMTLAKGLGSG-FPIGALIVGEKYQDI

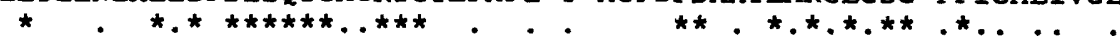

H. sap. IKPGEHGSTYGGNPLGCRVAIAALEVLEEENLAENADKLGIILRNELMKL---PSDVVTAVRGKG

S. cer. FTPGSHGSTFGGNPLASRVAIAALEVIRDEKLCQRAAQLGSSFIAQLKALQAKSNGIISEVRGMG

L. int. FTQGSHGSTFGGNHLAAAVAYETIRIIQTREI LNNVN ICSDIAFTRLREMQEKYP-VISEVRGKG

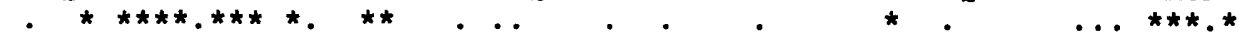

H. sap. LLNAIVIKETK- -DWDAWKVCLRLRDNGLLAKPTHGDIIRFAPPLVIKEDELRESIEIINKTILSF

S. cer. LLTAIVIDPSKANGKTAWDLCLLMKDQGLLAKPTHDHI IRLAPPLVISEEDLOTGVETIAKCIDLL

L. int. LHIGLELKVPS--RPIA-EACLSQGS

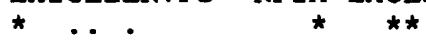

Fig. 5. Alignment of the amino acid sequences of the ORF1 protein and two ornithine aminotransferases. The sequences have been aligned using the MACAW program (Schuler et al., 1991). Where necessary, to enhance the alignments, gaps have been introduced and are indicated by dashes. An amino acid residue appearing in all of the sequences is indicated by an asterisk; when a residue appears in two of the three sequences and a related amino acid has been substituted in the third sequence, a dot is used. Abbreviations: $H$. sap., Homo sapiens; S. cer., Saccharomyces cerevisiae; L. int., Leptospira interrogans.

cloned DNA through nucleotide sequencing (see below). The $42 \mathrm{kDa}$ protein was found in the $\mathrm{Leu}^{+}$strains and was missing from the $\mathrm{Leu}^{-}$strains. Deletions within the putative leuB ORF inactivated the complementing activity, thus confirming that this ORF was necessary for the leuB-complementing activity. Deletions extending into either ORF1 or ORF2 had no effect on the leuBcomplementing activity of the clone. These results indicated that only the $42 \mathrm{kDa}$ protein was required for complementation of the leuB defect.

\section{Assay of $\beta$-isopropylmalate dehydrogenase from $L$. interrogans}

The product of the cloned $L$. interrogans leuB gene was tested to determine whether it could convert $\beta$-isopropylmalate to $\alpha$-ketoisocaproate. Crude cellular extracts were made from $L$. interrogans serovar pomona, E. coli, a leuB mutant of $E$. coli, and the $E$. coli leuB mutant transformed with pWVL11 to leucine prototrophy. These extracts were incubated at $37^{\circ} \mathrm{C}$ in the presence of $\beta$ isopropylmalate. The quantity of $\alpha$-ketoisocaproate produced in these experiments was determined colorimetrically by reaction with 2,4-dinitrophenylhydrazine and $\mathrm{KOH}$ (Parsons \& Burns, 1969). The reactions were linear for at least $20 \mathrm{~min}$; the specific activity of the enzyme was determined after $10 \mathrm{~min}$ of reaction. The results are shown in Table 1 . There was no detectable enzyme activity in the leuB mutant strain of $E$. coli. When this mutant strain was transformed with a plasmid containing the cloned gene, the specific activity of the enzyme was similar to that found in wild-type $E$. coli, indicating that the product of the cloned gene was a $\beta$ isopropylmalate dehydrogenase. The specific activity of 
the enzyme in the serovar pomona extract was fourfold lower than that seen in the extract from wild-type E. coli; this may be because the conditions used for the enzyme assay, while optimum for the enzyme from E. coli, may not be optimum for the enzyme from Leptospira. Alternatively, the leptospiral enzyme may have a lower activity, as the generation time of these cells is much longer than that of $E$. coli and there has been no evolutionary pressure to optimize the efficiency of the enzyme. The cloned enzyme in the $E$. coli extracts would show a higher specific activity due to gene dosage effects which lead to overproduction of the protein.

\section{Nucleotide sequencing and alignment of amino acid sequences}

To confirm the identity of the cloned gene and to determine the possible function of the DNA adjacent to the $\operatorname{le} u B$ gene, both strands of the leptospiral EcoRI DNA fragment found in pWVL6 were sequenced in their entirety. The resulting nucleotide sequence of serovar pomona DNA and the amino acid sequences deduced from the nucleotide data are shown in Fig. 3. Three ORFs, which encoded proteins of 40926 (ORF1), 38826 (leuB) and 15058 (ORF2) Da, were found. The location of the $38826 \mathrm{Da}$ ORF corresponds to the leuB functional region as defined by transposon mutagenesis (Fig. $1 b$ ). Each ORF was preceded by a potential Shine-Dalgarno sequence.

The inferred amino acid sequences of $l e u B$, ORF1 and ORF2 were used to search the PIR data bank for similar proteins. The amino acid sequence of the $\beta$-isopropylmalate dehydrogenase cloned from serovar pomona showed $43-57 \%$ identity and $19-26 \%$ related substitutions when compared with the same enzyme obtained from six different micro-organisms, Candida maltosa (Kawamura et al., 1983; Hamasawa et al., 1987), Saccharomyces cerevisiae (Andreadis et al., 1984), Bacillus coagulans (Sekiguchi et al., 1986), Thermus aquaticus (Sekiguchi et al., 1986), Bacillus subtilis (Sekiguchi et al., 1987) and Bacillus caldotenax (Sekiguchi et al., 1987). An alignment of the amino acid sequences of the 3-isopropylmalate dehydrogenases from $L$. interrogans and the other microorganisms is shown in Fig. 4. Conservation of amino acid sequence is seen throughout the protein.

The amino acid sequence of ORF1 shows about $58 \%$ similarity ( $32 \%$ identity and $26 \%$ related substitutions) with ornithine-oxoacid aminotransferase obtained from either Homo sapiens (Inana et al., 1986) or Saccharomyces cerevisiae (Degols, 1987). When the amino acid sequences of these proteins were aligned, several regions of strong homology were found (Fig. 5).

No proteins similar to ORF2 were found in the database. None of the cloned proteins had amino acid sequences similar to LeuA, LeuC or LeuD, the other leucine biosynthetic enzymes.

\section{Discussion}

A genomic library of $L$. interrogans serovar pomona DNA was constructed in the plasmid vector pUC13. A clone ( $\mathrm{pWVL1}$ ) was isolated from this genomic library which complemented three independent leuB mutations in $E$. coli. The leuB-complementing activity in PWVL1 was localized to approximately $1.2 \mathrm{~kb}$ of DNA by subcloning and by transposon mutagenesis using $\operatorname{Tn} 5$. Southern blot analysis of EcoRI-digested pWVL1 and serovar pomona DNAs revealed identically sized restriction fragments homologous to the cloned $l e u B$ gene. These data suggest that only a single form of the cloned leuB gene is present on the L. interrogans genome. No hybridization was detected with $E$. coli or L. biflexa serovar patoc DNAs. It is understandable that no crosshybridization occurred between $L$. interrogans and $L$. biflexa because previous studies have established that little, if any, DNA homology exists between these species (Brendle et al., 1974; Yasuda et al., 1987).

$\mathrm{Tn} 5$ insertions flanking the $l e u B$ gene did not inactivate gene expression, suggesting that expression of the gene depends on its own promoter rather than on a pUC13 promoter. It is unlikely that $\mathrm{Tn} 5$ promoters were used since $\mathrm{Tn} 5$ promoters are weak and generally do not allow expression of genes located outside of the element itself (Berg et al., 1980). While these results suggest that promoters may be located within the cloned Leptospira DNA, it is not clear whether these are native Leptospira promoters or merely sequences which fortuitously act as promoters in E. coli. Analysis of the sequence data revealed an E. coli $\sigma^{70}$-like promoter sequence (CTTACA... TTAAAT) located about 70 nucleotides upstream of the initiation codon of the leuB gene (Fig. 3). Mapping of the $5^{\prime}$ end of the leuB mRNA will be needed to determine whether this sequence is acting as a promoter in $E$. coli and whether it is the native promoter used by L. interrogans.

The close linkage of ORF1, leuB and ORF2 suggests that these genes might be transcribed as a unit. Consistent with such a possibility is the existence of an E. coli $\sigma^{70}$. like promoter sequence located upstream of ORF1. This promoter would have a -35 region of CTTCCG followed by a -10 region of TAAAAT (Hawley \& McClure, 1983). While the -35 region is not ideal and the spacing is only 15 nucleotides, the RNA polymerase isolated from spirochaetes has been shown to differ from that isolated from E. coli (Allan et al., 1986). The structural alteration found in the spirochaetal RNA polymerase may allow for some differences in promoter 
sequence and spacing when compared to the $E$. coli paradigm. Mapping of the promoters recognized by the leptospiral RNA polymerase will be needed to resolve this issue. Only one potential stem-loop-forming sequence is located within the sequenced DNA. It is found immediately downstream of ORF2 at nucleotides 3005 to 3084 and is followed by the sequence TTTTAT. This sequence might allow the stem-loop to function as a simple terminator (Platt, 1986). The existence of a potential promoter upstream of the sequenced DNA and of a potential terminator downstream of this DNA is consistent with the hypothesis that these genes may be transcribed as a unit.

Both strands of the $3 \cdot 1 \mathrm{~kb} E c o \mathrm{RI}$ fragment of pWVL6 (Fig. 3) were sequenced. Three open reading frames (ORFs) were present within this fragment. The predicted size of the protein encoded by the ORF spanning the $l e u B$ functional region as defined by $\operatorname{Tn} 5$ mutagenesis was $38826 \mathrm{Da}$. Further analysis, using subclones, confirmed that this ORF was necessary for complementation of a leuB mutation (Fig. 2).

The maxicell experiments (Fig. $2 b$ ) revealed that three proteins were encoded by the cloned DNA. The $42 \mathrm{kDa}$ protein was essential for expression of the LeuB ${ }^{+}$ phenotype. However, the 358 amino acid residues found in the le $B$ coding region constituted a molecular mass of $38826 \mathrm{Da}$. This value is about $7.5 \%$ less than that determined by SDS-polyacrylamide gel electrophoresis. The cause of the discrepancy could be anomalous SDS binding to the protein as was found with the leuB enzymes from $S$. cerevisiae and $B$. caldotenax (Andreadis et al., 1984; Sekiguchi et al., 1987). The $40 \mathrm{kDa}$ protein is the product of ORF1, since deletion of this ORF resulted in loss of the protein (Fig. $2 b$, lane C). The molecular mass of the protein encoded by ORF1, as calculated from its amino acid composition, is $40926 \mathrm{Da}$, which closely corresponds to the results obtained by maxicell analysis. Nucleotide sequence analysis identified another open reading frame, ORF 2 . The broad $14.5 \mathrm{kDa}$ band seen in lanes C and D of Fig. 2(b) may represent the product of ORF2, as it is approximately the correct size and is only seen in cells containing an intact ORF2.

The LeuB protein from $L$. interrogans is comparable in size to the $43 \mathrm{kDa}$ protein encoded by the $\operatorname{leu} B$ gene cloned from L. biflexa (Zuerner, 1986). Zuerner (1986) also found that his clone encoded proteins of approximately 46 and $15 \mathrm{kDa}$. The genes encoding these proteins could correspond to ORF 1 and ORF 2 found in the $L$. interrogans clone. If so, this would suggest a conservation of genetic organization in this region of the chromosome among the leptospiras.

Analysis of the amino acid sequence of the $\beta$ isopropylmalate dehydrogenase from $L$. interrogans showed the enzyme to have substantial amino acid sequence similarity with the $\beta$-isopropylmalate dehydrogenases from other micro-organisms (Fig. 4). The closest similarity is seen with the enzymes from the Bacillus species, and the least with the enzymes from the yeasts. This relationship is consistent with the evolutionary divergence of these organisms as proposed by Woese (1987).

The ORF for $l e u B$ begins with a methionine residue; in position 17 there is another methionine residue. The codon for the first methionine residue is likely to be the correct start codon because $(a)$ it is preceded by a Shine-Dalgarno sequence while the second methionine codon is not, and (b) alignment of the amino acid sequences of the various LeuB enzymes demonstrates that the first 17 residues are highly conserved (Fig. 4).

In $E$. coli and $S$. typhimurium the terminal step in leucine biosynthesis is catalysed by a non-specific aminotransferase (Calvo, 1983). These organisms can use either the aromatic transaminase ( $T y r B$ ) or the branched-chain amino acid transaminase (IlvE) to convert $\alpha$-ketoisocaproic acid to leucine. In our $L$. interrogans clone the close genetic linkage of ORF1 and leuB suggested that ORF1 might encode a protein functional in leucine biosynthesis. A search of the PIR data base detected similarity between the amino acid sequence of ORF1 and the ornithine aminotransferases obtained from $H$. sapiens and S. cerevisiae (Fig. 5). Since ornithine aminotransferases catalyse the reaction ornithine $+\alpha$-oxoacid $\rightarrow$ L-amino acid + glutamic semialdehyde, we hypothesize that the ORF1 product may function to catalyse the terminal step in leucine biosynthesis in Leptospira by transferring an amino group from ornithine to $\alpha$-ketoisocaproic acid to produce leucine.

Our sequence data indicate that the gene organization of $L$. interrogans differs from that found in other bacteria. In E. coli, S. typhimurium and B. subtilis, four contiguous structural genes, encoding the three enzymes required for leucine biosynthesis, are transcribed as a unit and comprise an operon (Burns et al., 1966; Somers et al., 1973; Ward \& Zahler, 1973). The leuA gene is located immediately upstream of the leuB gene and the leuC gene is located immediately downstream. In $L$. interrogans an ORF was found upstream of the $l e u B$ gene, but its protein product has no significant amino acid similarity to the leuA-encoded protein of S. typhimurium (Ricca \& Calvo, 1990). Immediately downstream of the leptospiral leuB gene was a small ORF encoding a basic protein. This protein shares no amino acid sequence similarity with the leuC gene from $S$. typhimurium (Rosenthal \& Calvo, 1990). Furthermore, the LeuC protein in other bacteria is larger and is not as basic (Umbarger, 1978). Thus the organization of the genes required for leucine biosynthesis in $L$. interrogans differs from that found in 
other bacteria. This is consistent with the findings of Richaud et al. (1990) and Zuerner (1986), who also found that their leuB leptospiral clones, although containing substantial amounts of contiguous DNA both upstream and downstream of the $l e u B$ gene, were unable to complement defects in other $E$. coli genes required for leucine biosynthesis.

We would like to thank Drs Marilyn Evans and Nyles Charon for their helpful discussions. Dr John Schloss kindly supplied us with the $\beta$-isopropylmalate used for these studies. This research was supported by USPHS grant DE04645, by NIH Biomedical Research grant 2S07RR05433, and by the WVU Medical and the WVU Dental Corporations.

\section{References}

Allan, B., Greenberg, E. P. \& Kropinski, A. (1986). DNA-dependent RNA polymerase from Spirochaeta aurantia. FEMS Microbiology Letters 35, 205-210.

Andreadis, A., Hsu, Y.P., Hermodson, M., Kohlhaw, G. \& SCHIMmel, P. (1984). Yeast LEU2. Journal of Biological Chemistry 259, 8059-8062.

BARTHOLOMEW, J. C. \& CALvo, J. M. (1971). 2-Isopropylmalate synthase from Salmonella typhimurium: carboxypeptidase digestion studies of parent and feedback-insensitive enzymes. Biochimica et Biophysica Acta 250, 568-576.

Berg, D. E., Weiss, A. \& Crossland, L. (1980). Polarity of Tn5 insertion mutation in Escherichia coli. Journal of Bacteriology 142, 439-446.

BRADFORD, M. M. (1976). A rapid and sensitive method for the quantitation of microgram quantities of protein utilizing the principle of protein-dye binding. Analytical Biochemistry 72, 248-254.

Brendle, J. J., Rogul, M. \& AleXander, A. D. (1974). Deoxyribonucleic acid hybridization among selected leptospiral isolates. International Journal of Systematic Bacteriology 24, 205-214.

DE BruiJn, F. J. \& LuPsKI, J. R. (1984). The use of transposon Tn5 mutagenesis in the rapid generation of correlated physical and genetic maps of DNA segments cloned into multicopy plasmids - a review. Gene 27, 131-149.

Burns, R. O., Calvo, J. M., Margolin, P. \& Umbarger, H. E. (1966). Expression of the leucine operon. Journal of Bacteriology 91, 1570-1576.

Calvo, J. M. (1983). Leucine biosynthesis in procaryotes. In Amino Acids - Biosynthesis and Genetic Regulation, pp. 267-284. Edited by K. M. Herrmann \& R. L. Somerville. Reading, MA: AddisonWesley.

Charon, N. W., Johnson, R. C. \& Peterson, D. (1974). Amino acid biosynthesis in the spirochete Leptospira: evidence for a novel pathway of isoleucine biosynthesis. Journal of Bacteriology 17, 203-211.

Chinault, A. C. \& Carbon, J. (1979). Overlap hybridization screening: isolation and characterization of overlapping DNA fragments surrounding the leu 2 gene on yeast chromosome III. Gene 5, 111-126.

DAvis, R. W., Botstein, D. \& Roth, J. R. (1980). Isolation of plasmid and bacterial DNA. In A Manual for Genetic Engineering: Advanced Bacterial Genetics, pp. 116-117. Cold Spring Harbor, NY: Cold Spring Harbor Laboratory.

DeGoLs, G. (1987). Functional analysis of the regulatory region adjacent to the $\operatorname{carg} B$ gene of Saccharomyces cerevisiae. European Journal of Biochemistry 169, 193-200.

Faine, S. \& Stallman, N. D. (1982). Amended description of the genus Leptospira Noguchi 1977 and the species L. interrogans (Stimson 1907) Wenyon 1926 and L. biflexa (Wolbach and Ringer 1914) Noguchi 1918. International Journal of Systematic Bacteriology 32, 461-463.

Fox, G. E., Stackebrandt, E., Hespell, R. B., Gibson, J., Dyer,
T. A., Wolfe, R. S., Balch, W. E., Tanner, R. S., Magrum, L. J., ZABlen, L. B., BlaKemore, R., GuPta, R., BONEN, L., Lewis, B. J., Stahl, D. A., Luehrsen, K. R., Chen, K. M. \& Woese, C. R. (1980). The phylogeny of procaryotes. Science 209, 457-463.

Friedberg, D., Rosenthal, E. R., Jones, J. W. \& Calvo, J. M. (1985). Characterization of $3^{\prime}$ end of the leucine operon of Salmonella typhimurium. Molecular and General Genetics 199, 486-494.

FuKANAGA, M. \& MifUCHI, I. (1989). Unique organization of Leptospira interrogans rRNA genes. Journal of Bacteriology 171, 5763-5767.

Gemmill, R. M., Wessler, S. R., Keller, E. B. \& Calvo, J. M. (1979). leu operon of Salmonella typhimurium is controlled by an attenuation mechanism. Proceedings of the National Academy of Sciences of the United States of America 76, 4941-4945.

Gemmill, R. M., Jones, J. W., Haughn, G. W. \& Calvo, J. M. (1983). Transcription initiation sites of the leucine operon of Salmonella typhimurium and Escherichia coli. Journal of Molecular Biology 170, 39-59.

Hamasawa, K., Kobayashi, Y., Harada, S., Yoda, K., Yamasaki, M. \& TAMURA, G. (1987). Molecular cloning and nucleotide sequence of the 3-isopropylmalate dehydrogenase gene of Candida utilis. Journal of General Microbiology 133, 1089-1097.

HAWLEY, D. K. \& MCCluRE, W. R. (1983). Compilation and analysis of Escherichia coli promoter DNA sequences. Nucleic Acids Research 11, 2237-2255.

HENIKOFF, S. (1984). Unidirectional digestion with exonuclease III creates targeted breakpoints for DNA sequencing. Gene 28, 351-359.

HolT, S. C. (1978). Anatomy and chemistry of spirochetes. Microbiological Reviews 42, 114-160.

Hottinger, H., Ohgi, T., Zwahlen, M. C., Dhamija, S. \& Soll, D. (1987). Allele-specific complementation of an Escherichia coli leuB mutation by a Lactobacillus bulgaricus tRNA gene. Gene 60, 75-83.

Inana, G., Totsuka, S., Redmond, M., Dougherty, T., NAgle, J., Shiono, T., Ohura, T., Kominami, E. \& Katunuma, N. (1986). Molecular cloning of human ornithine aminotransferase mRNA. Proceedings of the National Academy of Sciences of the United States of America 83, 1203-1207.

IsH-HoRowicz, D. \& BURKE, J. F. (1981). Rapid and efficient cosmid cloning. Nucleic Acids Research 9, 2989-2996.

Johnson, R. C. (1977). The spirochetes. Annual Review of Microbiology 31, 89-106.

Johnson, R. C. (1981). Aerobic spirochetes. In The Prokaryotes, pp. 582-591. Edited by M. Starr, H. Stolp, H. G. Trüper, A. Balows \& H. G. Schlegel. New York: Springer-Verlag.

JoHnson, R. C. \& HaRRIS, V. G. (1967). Differentiation of pathogenic and saprophytic leptospiras. I. Growth at low temperature. Journal of Bacteriology 94, 27-31.

Kawamura, M., Takagi, M. \& Yano, K. (1983). Cloning of a $L E U$ gene and an ARS site of Candida maltosa. Gene 24, 157-162.

KUSHNER, S. R. (1978). An improved method for transformation of Escherichia coli with ColE1 derived plasmids. In Genetic Engineering, pp. 17-23. Edited by H.W. Boyer \& S. Nicosia. Amsterdam: Elsevier/North-Holland Biomedical Press.

Lawn, R. M., Fritsch, E. F., Parker, R. C., Blake, G. \& Maniatis, T. (1978). The isolation and characterization of a linked $\alpha$ - and $\beta$ globin gene from a cloned library of human DNA. Cell 15, $1157-1174$.

Maniatis, T., Fritsch, E. F. \& Sambrook, J. (1982). Molecular Cloning: a Laboratory Manual. Cold Spring Harbor, NY: Cold Spring Harbor Laboratory.

PARSONS, S. J. \& BuRns, R. O. (1969). Purification and properties of $\beta$ isopropylmalate dehydrogenase. Journal of Biological Chemistry 244 , 996-1003.

Paster, B. J., Stackebrandt, E., Hespell, R. B., Hahn, C. M. \& WOESE, C. R. (1984). The phylogeny of the spirochetes. Systematic and Applied Microbiology 5, 337-351.

PlatT, T. (1986). Transcription termination and the regulation of gene expression. Annual Review of Biochemistry 55, 339-372.

Ricca, E. \& CALvo, J. M. (1990). The nucleotide sequence of leuA from Salmonella typhimurium. Nucleic Acids Research 18, 1290.

Richaud, C., Margarita, D., Baranton, G. \& Saint Girons, I. (1990). Cloning of genes required for amino acid biosynthesis from 
Leptospira interrogans serovar icterohaemorrhagiae. Journal of General Microbiology 136, 651-656.

Rosenthal, E. R. \& Calvo, J. M. (1990). The nucleotide sequence of leuC from Salmonella typhimurium. Nucleic Acids Research 18, 3072.

Sancar, A., Hack, A. M. \& Rupp, W. D. (1979). Simple method for identification of plasmid-coded proteins. Journal of Bacteriology 137, 692-693.

SANGer, F., Nicklen, S. \& Coulson, A. R. (1977). DNA sequencing with chain-terminating inhibitors. Proceedings of the National Academy of Sciences of the United States of America 74, 5463-5467.

Schuler, G. D., Altshul, S. F. \& Lipman, D. J. (1991). A workbench for multiple alignment construction and analysis. Proteins: Structure, Function and Genetics 9, 180-190.

Searles, L. L., Wessler, S. R. \& Calvo, J. M. (1983). Transcription attenuation is the major mechanism by which the leu operon of Salmonella typhimurium is controlled. Journal of Molecular Biology 163, 377-394.

Sekiguchi, T., Ortega-Cesena, J., Nosoh, Y, Ohashi, S., Tsuda, K. \& KANAYA, S. (1986). DNA and amino acid sequences of 3isopropylmalate dehydrogenase of Bacillus coagulans. Comparison with the enzymes of Saccharomyces cerevisiae and Thermus thermophilus. Biochimica et Biophysica Acta 867, 36-44.

SekiguChI, T., Suda, M., IshiI, T., Nosoh, Y. \& Tsuda, K. (1987). The nucleotide sequence of 3-isopropylmalate dehydrogenase gene from Bacillus caldotenax. Nucleic Acids Research 15, 853.

Somers, J. M., Amzallag, A. \& Middleton, R. B. (1973). Genetic fine structure of the leucine operon of Escherichia coli K-12. Journal of Bacteriology 113, 1268-1272.
UMBarger, H. E. (1978). Amino acid biosynthesis and its regulation. Annual Review of Biochemistry 47, 533-606.

VIEIRA, J. \& Messing, J. (1982). The pUC plasmids, an M13mp7derived system for insertion mutagenesis and sequencing with synthetic universal primers. Gene 19, 259-268.

WARD, J. B. \& ZAHLER, S. A. (1973). Regulation of leucine biosynthesis in Bacillus subtilis. Journal of Bacteriology 116, 727-735.

Westrall, H. N., Charon, N. W. \& Peterson, D. E. (1983). Multiple pathways for isoleucine biosynthesis in the spirochete Leptospira. Journal of Bacteriology 154, 846-853.

WOESE, C. R. (1987). Bacterial evolution. Microbiological Reviews 51 , 221-271.

Yasuda, P. H., Steigerwalt, A. G., Sulzer, K. R., Kaufmann, A. F., Rogers, F. \& BRENnER, D. J. (1987). Deoxyribonucleic acid relatedness between serogroups and serovars in the family Leptospiraceae with proposals for seven new Leptospira species. International Journal of Systematic Bacteriology 37, 407-415.

Yelton, D. B. \& ChaRon, N. W. (1984). Cloning of a gene required for tryptophan biosynthesis from Leptospira biflexa serovar patoc into Escherichia coli. Gene 28, 147-152.

Yelton, D. B. \& Peng, S. L. (1989). Identification and nucleotide sequence of the Leptospira biflexa serovar patoc trpE and trpG genes. Journal of Bacteriology 171, 2083-2089.

ZUERNER, R. L. (1986). Cloning and analysis of Leptospira genes. PhD dissertation, West Virginia University, Morgantown, WV, USA.

ZuERNER, R. L. \& CHARON, N. W. (1988). Nucleotide sequence analysis of a gene cloned from Leptospira biflexa serovar patoc which complements an $\arg E$ defect in Escherichia coli. Journal of Bacteriology 170, 4548-4554. 